\title{
Improvement of Cell Cycle Lifespan and Genetic Damage Susceptibility of Human Mesenchymal Stem Cells by Hypoxic Priming
}

\author{
Chang-Woo Lee ${ }^{1,2}$, Dongrim Kang ${ }^{1,3}$, Ae-Kyeong Kim ${ }^{3}$, Dong-Young Kim ${ }^{1}$, Dong-Ik Kim ${ }^{3}$ \\ ${ }^{I}$ Department of Molecular Cell Biology, Samsung Medical Center, Sungkyunkwan University School of Medicine, Suwon, \\ ${ }^{2}$ Department of Health Sciences and Technology, SAIHST, Sungkyunkwan University, Suwon, \\ ${ }^{3}$ Division of Vascular Surgery, Samsung Medical Center, Sungkyunwan University School of Medicine, Seoul, Korea
}

Hypoxic culture is widely recognized as a method to efficiently expand human mesenchymal stem cells (MSCs) without loss of stem cell properties. However, the molecular basis of how hypoxia priming benefits MSC expansion remains unclear. We report that hypoxic priming markedly extends the cell cycle lifespan rather than augmenting the multipotency of MSC differentiation lineage. Hypoxic priming does not affect to chromosome damage but significantly attenuates the susceptibility of chromosome damage. Our results provide important evidence that multipotency of human MSCs by hypoxic priming is determined by cell cycle lifespan.

Keywords: Mesenchymal stem cells, Hypoxia, Cell cycle, Senescence, Chromosome damage, Multipotency

\section{Introduction}

Human mesenchymal stem cells (MSCs) are able to self-renew or differentiate to other lineages (1-3), and these cells have been isolated from different tissues such

Received: September 10, 2017, Revised: November 28, 2017,

Accepted: December 6, 2017, Published online: April 30, 2018

Correspondence to Chang-Woo Lee

Department of Molecular Cell Biology, Samsung Medical Center,

Sungkyunkwan University School of Medicine, 2066 Seobu-ro, Jangan-gu, Suwon 16419, Korea

Tel: +82-31-299-6153, Fax: +82-31-299-6109

E-mail: cwlee1234@skku.edu

Co-Correspondence to Dong-Ik Kim

Division of Vascular Surgery, Samsung Medical Center, 81 Irwon-ro, Gangnam-gu, Seoul 06351, Korea

Tel: +82-2-3410-3467, Fax: +82-2-3410-0040

E-mail: dikim@skku.edu

(a) This is an open-access article distributed under the terms of the Creative Commons Attribution Non-Commercial License (http://creativecommons.org/ licenses/by-nc/4.0/), which permits unrestricted non-commercial use, distribution, and reproduction in any medium, provided the original work is properly cited.

Copyright (c) 2018 by the Korean Society for Stem Cell Research as brain, liver, bone marrow, adipose tissue, foetal tissues, umbilical cord (UC), and placenta (4-7). Various types of human mesenchymal stem cells (MSCs) reside in the hypoic microenvironment, which seems to be conductive to stem cell longevity and the physiological niches $(8,9)$. Hypoxia has a strong effect on several aspects of cell biology such as metabolism, angiogenesis, innate immunity and stemness induction, and hypoxic is also essential for the self-renewal and the maintenance of multipotency of human MSCs and hematopoietic stem cells (HSCs) (9-11). In recent years, many studies support that the hypoxic culture of human MSCs inhibits cellular senescence, maintains MSCs properties, augments the differentiation capacity, and enhances their tissue regenerative potential, indicating that hypoxia increases the lifespan and the differentiation potential of MSCs (10-13).

MSCs-based cell therapy is a potential therapeutic approach for the treatment of various diseases, including stroke and myocardial infarction (14-17), traumatic brain injuries (18), diabetes mellitus (19), inflammatory bowel disease (20), and acute kidney $(21,22)$ and liver injuries (23-25). However, the large amount of engrafted MSCs de- 
creased dramatically after transplantation due to immune rejection and toxic microenvironments. Thus, adopting appropriate priming strategies provide an effective way of promoting survival and avoiding immune rejection (14). In addition, recent studies have also shown that hypoxic priming induces the expression of pro-survival markers (26), and growth factors involved in cell proliferation, anti-apoptosis and angiogenesis (27) in MSCs. However, it is not yet clear whether the benefit of hypoxic priming is the expansion, cellular longevity, or multi-potent differentiation capacity of human MSCs. In this study, we found that hypoxic priming extends cell cycle lifespan but reduce genetic damage susceptibility, and thus maintain the multipotency of MSCs during differentiation lineage.

\section{Materials and Methods}

\section{Cell culture}

Human umbilical cord blood derived mesenchymal stem cells (hUCB-MSCs; PromoCell) were grown in Dulbecco's Modified Eagle's Medium (DMEM; Hyclone) containing $10 \%$ fetal bovine serum (FBS; GIBCO) and $1 \%$ Penicillin/Streptomycin antibiotics at $37^{\circ} \mathrm{C}$ in a $5 \% \mathrm{CO}_{2}$ incubator with $21 \% \mathrm{O}_{2}$ (normoxia) or $1 \% \mathrm{O}_{2}$ (hypoxia).

\section{Carboxyfluorescein succinimidyl ester (CFSE) assay}

For assessment of the potential of cell proliferation, MSCs were trypsinized and washed once with phosphate buffered saline (PBS). CFSE (Invitrogen, $10 \mathrm{mM}$ in PBS) was added to the cells and incubated at $37^{\circ} \mathrm{C}$ in the dark for $15 \mathrm{~min}$. An equal volume of serum containing growth medium was added for quench the CFSE reaction. Cells were again incubated at $37^{\circ} \mathrm{C}$ in the dark for $5 \mathrm{~min}$. CFSE-labeled MSCs were washed twice with growth medium and seeded in a culture plate.

\section{Senescence associated $\beta$-galactosidase ( $\beta$-gal) assay}

Cells were fixed with $4 \%$ formaldehyde for $10 \mathrm{~min}$ and incubated overnight at $37^{\circ} \mathrm{C}$ with $1 \mathrm{mg} / \mathrm{ml} \mathrm{X}$-gal (5-bromo-4 chloro-3-indolyl- $\beta$-D-galactopyranoside), $5 \mathrm{mM} \mathrm{K}_{3} \mathrm{Fe}(\mathrm{CN})_{6}$, $5 \mathrm{mM} \mathrm{K}_{4} \mathrm{Fe}(\mathrm{CN})_{6}, 150 \mathrm{mM} \mathrm{NaCl}$, and $2 \mathrm{mM} \mathrm{MgCl}_{2}$ in $40 \mathrm{mM}$ citric acid/sodium phosphate $\mathrm{pH}$ 6.0.

\section{Immunofluorescence}

hUCB-MSCs were grown on coverslips $\left(1 \times 10^{4}\right.$ cells) for 2 days. Cells were fixed with $4 \%$ formaldehyde in PBS for 10 min and rinsed three times with a wash solution of $(0.1 \%$ Triton X-100 in PBS. Cells were blocked with 3\% skim milk/wash solution for $30 \mathrm{~min}$ and incubated with primary antibody (1:200) and secondary antibody (1:200) for $1 \mathrm{hr}$.

\section{Metaphase chromosome spreading assay}

Cells were incubated with colcemid (final concentration $100 \mathrm{ng} / \mathrm{ml}$ ) for cell cycle arrest around metaphase. Mitotic cells were then collected by gentle pipetting, washed with PBS twice, counted, and suspended in a hypotonic solution $(0.8 \%$ sodium citrate). After $15 \mathrm{~min}$ incubation at room temperature, swelled cells were centrifuged $(1,000$ $\left.\mathrm{rpm}, 4 \mathrm{~min}, 4^{\circ} \mathrm{C}\right)$. Most of the supernatant was aspirated and the pellet was gently in the remaining approximately $500 \mu 1$ of supernatant. Carnoy's fixative solution $(75 \%$ methanol, 25\% acetic acid) was slowly added and incubated at room temperature for $10 \mathrm{~min}$. The fixation was repeated 3 4 more times. The suspended cells were dropped onto cold wet slides and allowed to dry at room temperature. The slides were mounted and examined by fluorescence microscopy (Carl Zeiss).

\section{Statistical analysis}

All data were presented as means \pm standard errors of means (SEMs). Statistical analyses were performed using the Student $t$ test.

\section{Fluorescence-activated cell sorting (FACS)}

Human UCB-MSCs were evaluated using surface marker detection at passage 5 (P5) to confirm the effect of oxygen concentration (hypoxia and normoxia) on MSC characterization. hUCB-MSCs at $80 \%$ confluence were harvested and suspended in FACS buffer $\left(1 \times 10^{7}\right.$ cells $\left./ \mathrm{ml}\right)$. Antibody was then added to each samples: Anti-CD90 fluorescein isothiocyanate (FITC), Anti-CD44 phycoerythrin (PE), Anti-CD105-PerCP-Cy5.5, Anti-CD73-allophycocyanin (APC), MSC negative antibodies set (Anti-CD34/CD11b/ CD19/CD45/HLA-DR-PE), positive isotype cocktail (mIgGFITC, mIgG-PerCP-Cy5.5, mIgG-APC), negative isotype cocktail (mIgG1-PE, mIgG2a-PE) (562245, BD Biosciences) followed by incubation at $4^{\circ} \mathrm{C}$ for $30 \mathrm{~min}$. For cell cycle analysis using propidium iodide, cells were fixed with cold $70 \%$ ethanol overnight at $-20^{\circ} \mathrm{C}$. They were then washed once with PBS and incubated in PBS containing $50 \mu \mathrm{g} / \mathrm{ml}$ propidium iodide and $1 \mathrm{mg} / \mathrm{ml}$ RNase A for $30 \mathrm{~min}$ at room temperature. After staining, cells were washing with PBS and measured by flow cytometry. Antibodies listed above are purchased from $\mathrm{BD}$ Biosciences.

\section{Results and Discussion}

\section{Hypoxia extends cell cycle lifespan and multi-potency of humans MSCs}

To delineate the key mechanistic benefit of hypoxic priming, human MSCs were isolated from human umbilical 
A

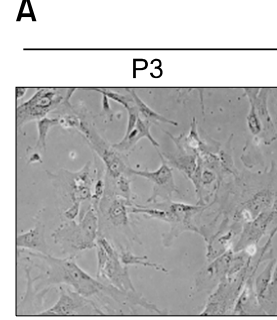

Normoxia
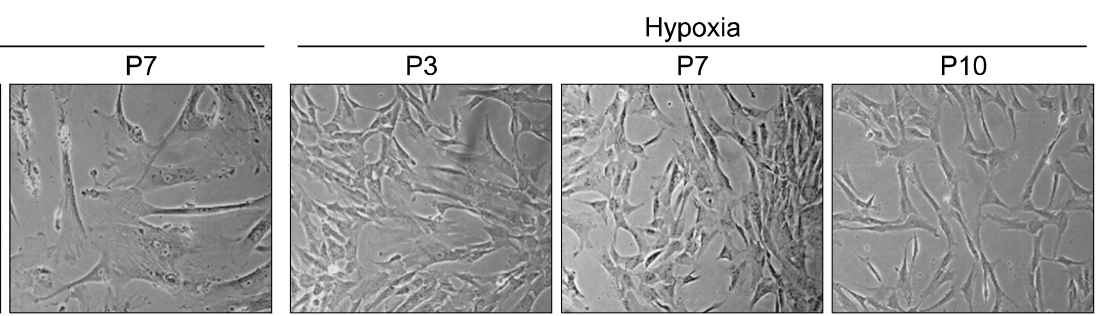

B
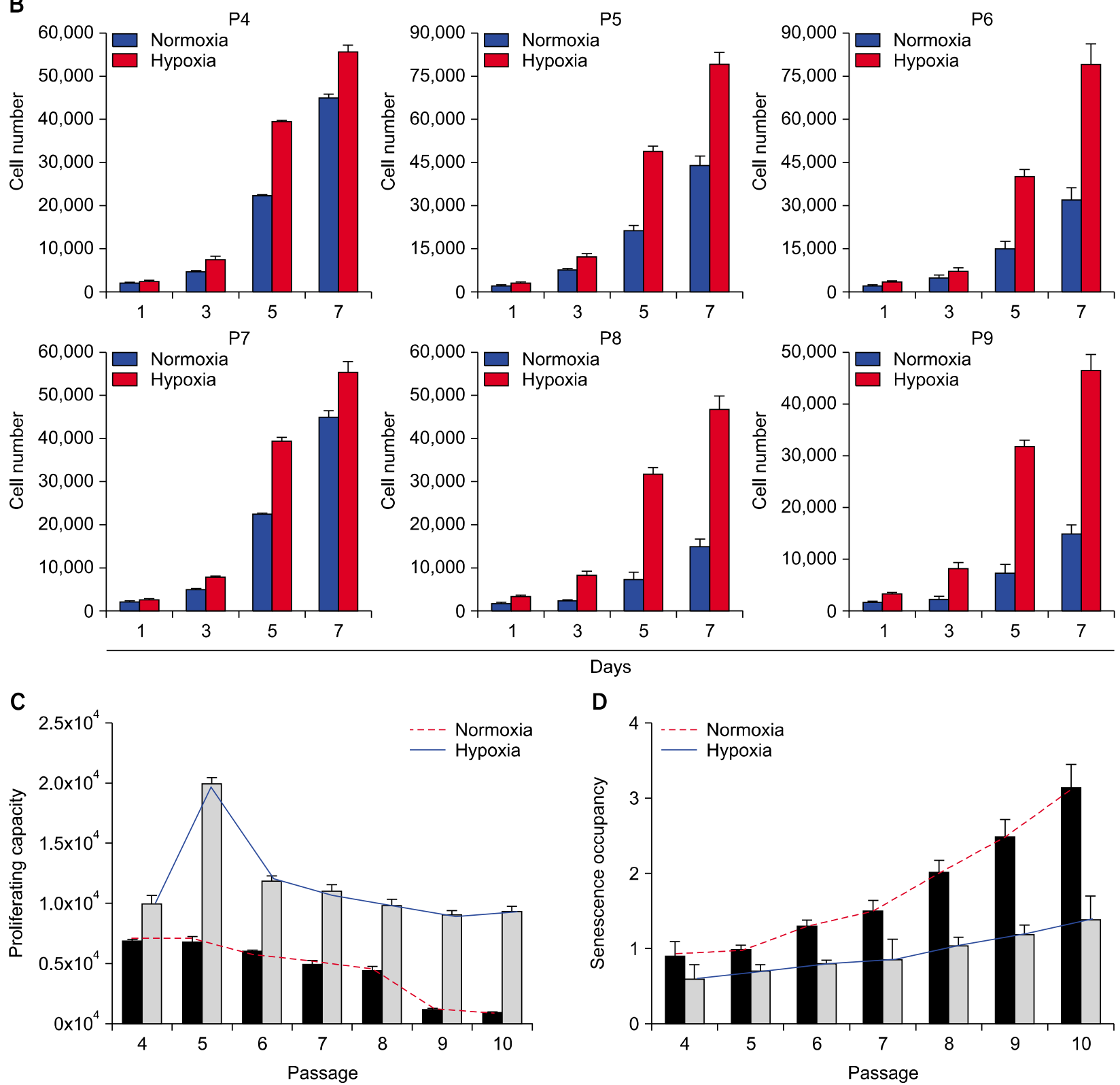

Fig. 1. Comparison of potentialities of proliferation, multipotency, and senescence between normoxic and hypoxic conditioning. (A) Phase contrast images of human umbilical cord blood-derived MSCs (MSCs) were cultured in normoxic $\left(21 \% \mathrm{O}_{2}\right)$ or hypoxic $\left(1 \% \mathrm{O}_{2}\right)$ conditions through multiple passages (passages 3, 5 and 7, respectively). (B) Several different passages of MSCs derived from the same source of MSCs were further cultured in normoxic $\left(21 \% \mathrm{O}_{2}\right)$ and hypoxic $\left(1 \% \mathrm{O}_{2}\right)$ conditions, and cell numbers were counted at designated times. (C) The graph shows the relative comparison of proliferating cell number following normoxic or hypoxic priming at several passages of MSCs culture. (D) The graph shows the relative incidence of senescence associated $\beta$-galactosidase positive MSCs. Data (mean \pm SEM) are representative of 3 independent experiments. 
cord blood (UCB) by adhesion to tissue culture-coated plates in complete culture medium as previously described (14). Culture passaging generated a homogenous population of UCB-MSCs (hereafter MSCs) that were used to measure proliferation rate, multi-potency, and senescence (Fig. 1A 1C). Human MSCs were cultured under normoxic ( $21 \%$ oxygen) or hypoxic ( $1 \%$ oxygen) conditions. When the culture became nearly confluent, the cells were
A

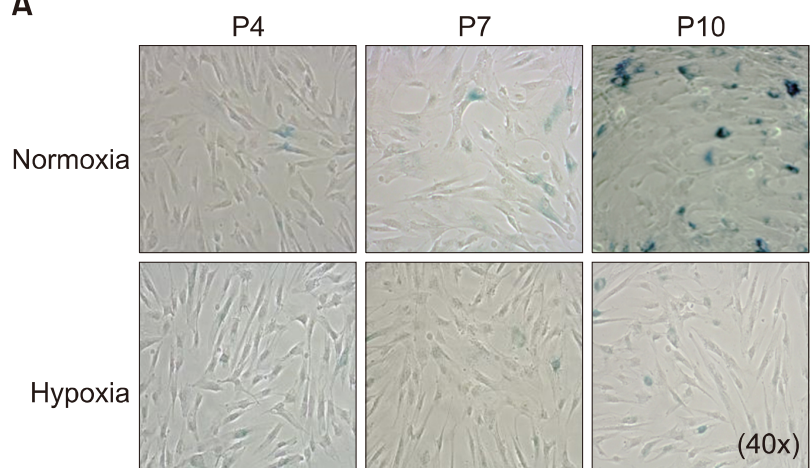

B
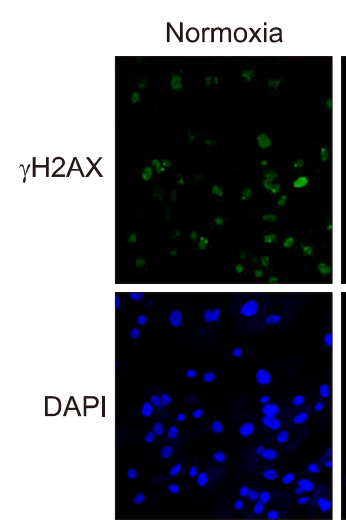

C
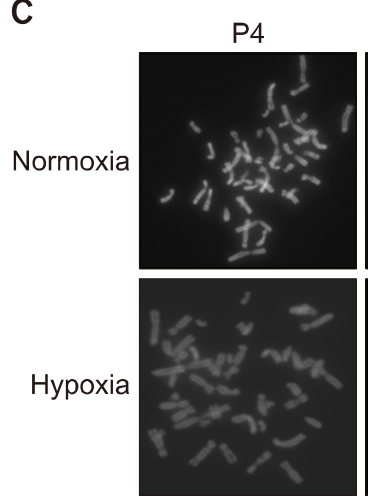

Hypoxia

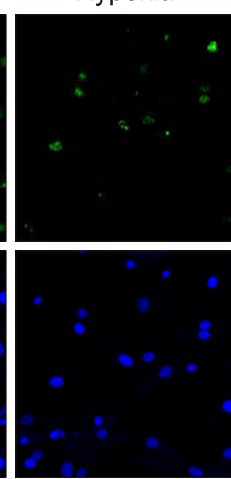

P8

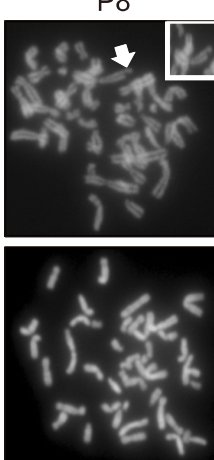

Doxo $0.5 \mathrm{mM}$ Normoxia
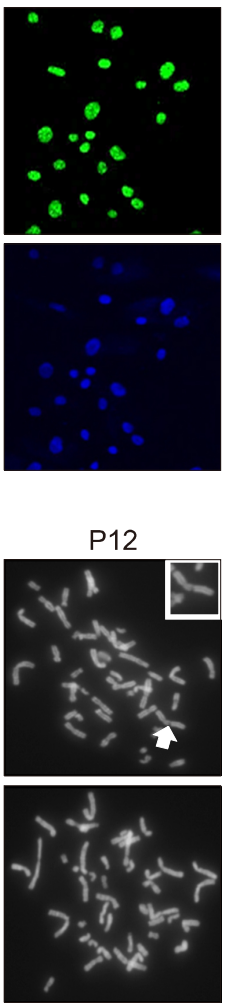
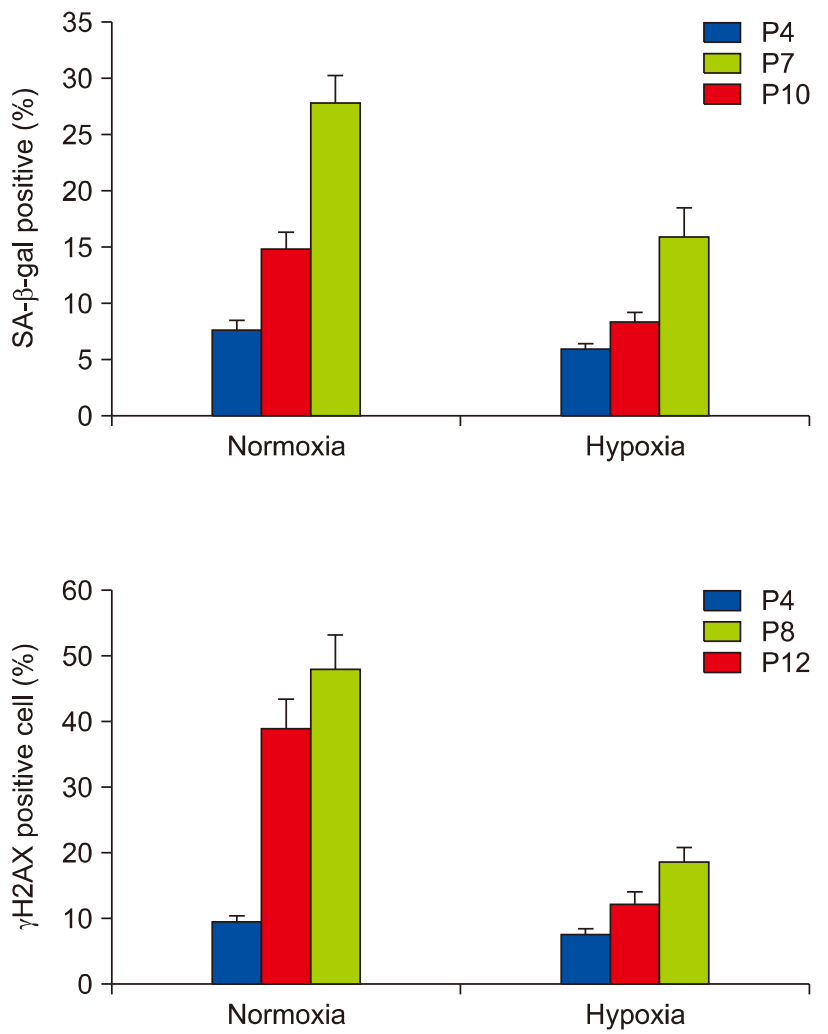

D
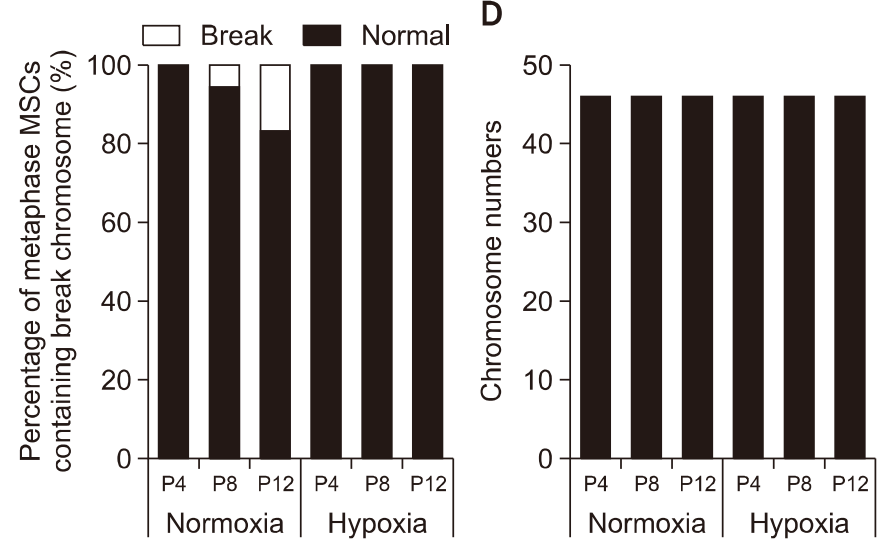

Fig. 2. Effect of hypoxic priming on the DNA and chromosome damage and senescence of MSCs. (A) Three different passages of MSCs grown in normoxic or hypoxic condition were analyzed by senescence associated $\beta$-galactosidase (SA- $\beta$-gal) staining. The graph shows the relative percentage of SA- $\beta$-gal positive cells. (B) MSCs were cultured in normoxic or hypoxic condition, or in normoxic condition in combination with $0.5 \mathrm{mM}$ doxorubicin (Doxo) treatment, and stained with anti- $\gamma \mathrm{H} 2 \mathrm{AX}$ (a marker for DNA double-strand breaks) and DAPI for DNA. Graph shows the percentage of $\gamma \mathrm{H} 2 \mathrm{AX}$-positive cells at three different passages. (C) Three different passages of MSCs were grown in normoxic or hypoxic condition, and harvested for metaphase chromosome spreading analysis. Arrows indicate the break chromosome. The graphs show the percentage of metaphase MSCs containing the break chromosome. (D) Total number of chromosome in each MSC was examined at passages 4, 8, and 12, respectively. Data (mean \pm SEM) are representative of 3 independent experiments. 
A
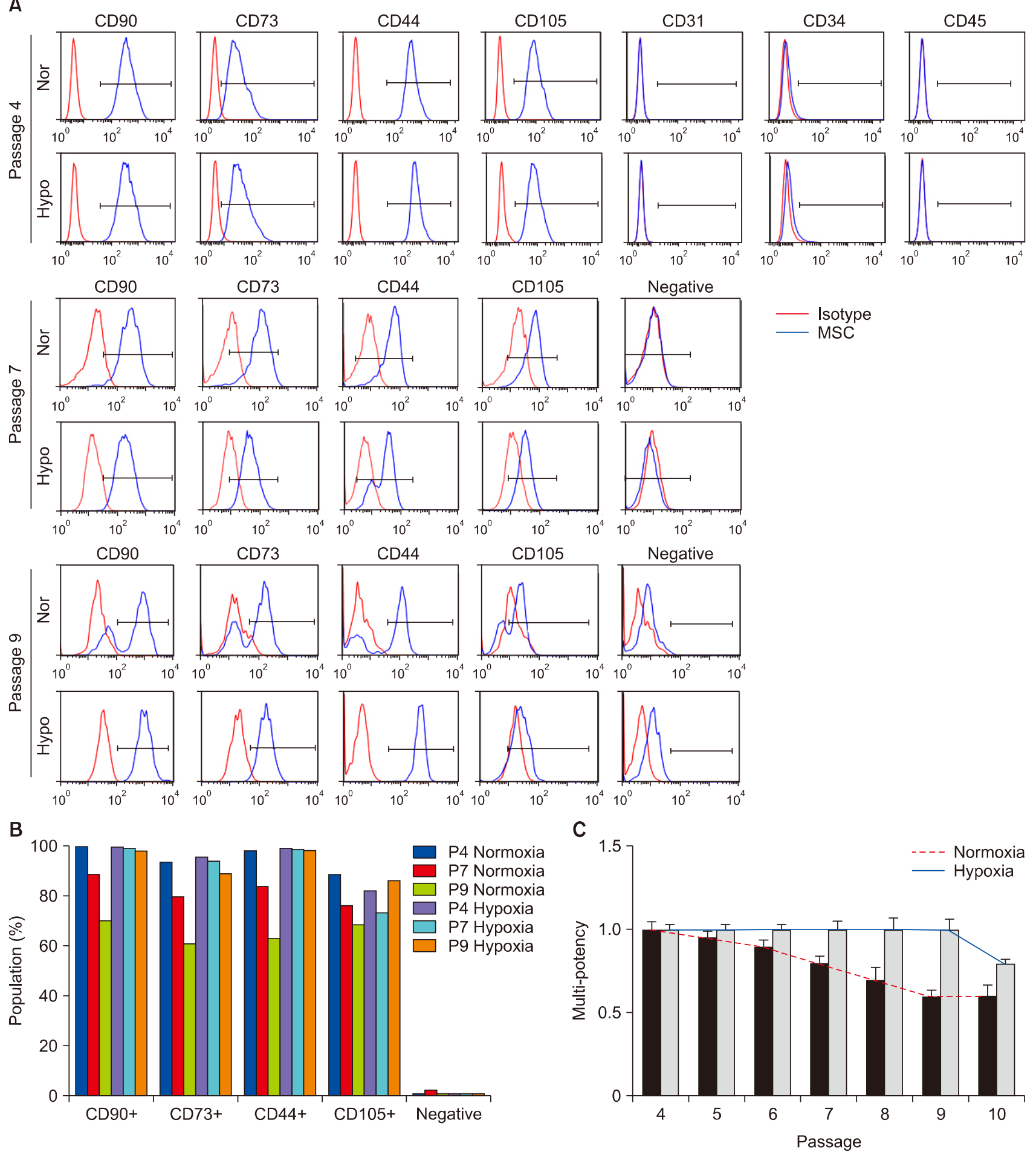

Fig. 3. Application of hypoxia to MSCs stimulates their proliferating potential and the potential of multi-lineage differentiation. (A) Multi-passaged MSCs were cultured in normoxic or hypoxic condition, labeled with antibodies against specific surface antigens, CD44, CD73, CD90, and CD105 for MSC positive markers and CD31, CD34, and CD45 for MSC negative markers, and analyzed by counting 10,000 cells at passages 4, 7, and 9, respectively. The surface antigen phenotype was characterized by FACS. Immunoglobulin isotype was used as a negative control for FACS analysis. Negative indicates the labelling of cells with CD34, CD45, and CD11b antibodies. Red-colored histograms illustrate the control immunoglobulin, and blue-colored histograms represent the staining against each specified antibodies as indicated. (B) The graph shows the positive percentages of each MSC marker expression. (C) The graph shows the potency of adipogenic differentiation rate at indicated passages. Data $($ mean \pm SEM) are representative of 3 independent experiments. 
trypsinized and subcultivated. As expected, hypoxia significantly accelerated the proliferation rate and extended the life span of human MSCs compared to normoxic cultures (Fig. 1B and 1C). Similar results were obtained with MSCs from two different donors (data not shown).

Under the hypoxic condition, late passaged MSCs continuously proliferated and maintained a similar morphology as early passaged cells (Fig. 1B and 1C). However, most of late passaged MSCs (passage 8 and later) cultured in the normoxic condition almost completely lost their proliferation capacity and adopted a flat, enlarged shape and ceased proliferation at subconfluent densities, thus manifesting characteristics of senescence (Fig. 2A), indicating that hypoxia extended the cell proliferation life span of MSCs. In support of this notion, cytochemical senescent phenotype analysis involving staining of the senescence-associated $\beta$-galactosidase (SA $\beta$-Gal) showed that cells in normoxic cultures of late passaged MSCs mostly displayed SA $\beta$-Gal activity, while hypoxic cultures showed significantly less amounts of SA $\beta$-Gal staining (Figs. 1D and 2A). In addition, the percentage of $y_{\circ} \mathrm{H} 2 \mathrm{AX}$-positive cells (as a marker for DNA double strand breaks) was markedly decreased compared to normoxic culture (Fig. 2B). Further metaphase chromosome spreading assays also showed significantly less population of MSCs with chromosome damage (Fig. 2B and 2C). Together, these results indicate that hypoxia extends cell cycle lifespan but reduces chromosome damage susceptibility.

\section{Uncoupling between cell cycle lifespan and multi-potency of hypoxic primed humans MSCs}

Multi-potency of MSCs by normoxic and hypoxic priming was compared by the examination of the surface expression of multi-potent MSC antigenic markers. Positive markers included CD44, CD73, CD90, and CD105. Negative markers included CD34, CD45, CD11b, and/or CD19 (Fig. 3A and 3B). Unexpectedly, early and middle passage MSCs (passages 4 and 7, respectively) grown under normoxic or hypoxic condition showed very similar levels of surface $\mathrm{CD}$ marker profiles; cells were consistently positive for CD44, CD73, CD90, and CD105, and negative for CD34, CD45, CD11b, and/or CD19 (Fig. 3B and $3 \mathrm{C}$ ), indicating that hypoxic priming does not augment the differentiation capacity of MSCs at early and intermediate passages. However, although hypoxic conditioning drastically extended the cell cycle lifespan and delayed senescence in late passaged MSCs, comparison of the multi-potency by measuring the same number of cells revealed that normoxic primed late passaged MSCs still retained the significant capacity of multi-potency com- pared to hypoxic conditioning. These results raise the important notion that hypoxic priming is an efficient tool for expanding the actively proliferating pool of MSCs, but not for augmentation of their multi-potency. The multi-potency of MSCs may be able to be determined by measuring their proliferating potential and/or strength of cell cycle lifespan, but not by the expressions of pre-existing MSC markers.

\section{Acknowledgments}

This study was supported by a National Research Foundation grant funded by the Korean government (MEST) (2017R1A2B3006776 and 2014R1A2A1A10050775).

\section{Potential Conflict of Interest}

The authors have no conflicting financial interest.

\section{References}

1. Anderson DJ, Gage FH, Weissman IL. Can stem cells cross lineage boundaries? Nat Med 2001;7:393-395

2. Jiang Y, Jahagirdar BN, Reinhardt RL, Schwartz RE, Keene CD, Ortiz-Gonzalez XR, Reyes M, Lenvik T, Lund T, Blackstad M, Du J, Aldrich S, Lisberg A, Low WC, Largaespada DA, Verfaillie CM. Pluripotency of mesenchymal stem cells derived from adult marrow. Nature 2002;418:41-49

3. Mohammadian M, Shamsasenjan K, Lotfi Nezhad P, Talebi M, Jahedi $M$, Nickkhah $H$, Minayi N, Movassagh Pour A. Mesenchymal stem cells: new aspect in cell-based regenerative therapy. Adv Pharm Bull 2013;3:433-437

4. Momin EN, Mohyeldin A, Zaidi HA, Vela G, QuiñonesHinojosa A. Mesenchymal stem cells: new approaches for the treatment of neurological diseases. Curr Stem Cell Res Ther 2010;5:326-344

5. da Silva Meirelles L, Chagastelles PC, Nardi NB. Mesenchymal stem cells reside in virtually all post-natal organs and tissues. J Cell Sci 2006;119:2204-2213

6. Romanov YA, Svintsitskaya VA, Smirnov VN. Searching for alternative sources of postnatal human mesenchymal stem cells: candidate MSC-like cells from umbilical cord. Stem Cells 2003;21:105-110

7. Fukuchi Y, Nakajima H, Sugiyama D, Hirose I, Kitamura T, Tsuji K. Human placenta-derived cells have mesenchymal stem/progenitor cell potential. Stem Cells 2004;22: 649-658

8. Davy P, Allsopp R. Hypoxia: are stem cells in it for the long run? Cell Cycle 2011;10:206-211

9. Tsai CC, Chen YJ, Yew TL, Chen LL, Wang JY, Chiu CH, Hung SC. Hypoxia inhibits senescence and maintains mesenchymal stem cell properties through down-regulation of E2A-p21 by HIF-TWIST. Blood 2011;117:459-469

10. Rosová I, Dao M, Capoccia B, Link D, Nolta JA. Hypoxic preconditioning results in increased motility and improved 
therapeutic potential of human mesenchymal stem cells. Stem Cells 2008;26:2173-2182

11. Suda T, Takubo K, Semenza GL. Metabolic regulation of hematopoietic stem cells in the hypoxic niche. Cell Stem Cell 2011;9:298-310

12. Mathieu J, Zhou W, Xing Y, Sperber H, Ferreccio A, Agoston Z, Kuppusamy KT, Moon RT, Ruohola-Baker H. Hypoxia-inducible factors have distinct and stage-specific roles during reprogramming of human cells to pluripotency. Cell Stem Cell 2014;14:592-605

13. Zhang J, Nuebel E, Daley GQ, Koehler CM, Teitell MA. Metabolic regulation in pluripotent stem cells during reprogramming and self-renewal. Cell Stem Cell 2012;11: 589-595

14. Theus MH, Wei L, Cui L, Francis K, Hu X, Keogh C, Yu SP. In vitro hypoxic preconditioning of embryonic stem cells as a strategy of promoting cell survival and functional benefits after transplantation into the ischemic rat brain. Exp Neurol 2008;210:656-670

15. Francis KR, Wei L. Human embryonic stem cell neural differentiation and enhanced cell survival promoted by hypoxic preconditioning. Cell Death Dis 2010;1:e22

16. Jaussaud J, Biais M, Calderon J, Chevaleyre J, Duchez P, Ivanovic Z, Couffinhal T, Barandon L. Hypoxia-preconditioned mesenchymal stromal cells improve cardiac function in a swine model of chronic myocardial ischaemia. Eur J Cardiothorac Surg 2013;43:1050-1057

17. Muscari C, Giordano E, Bonafè F, Govoni M, Pasini A, Guarnieri C. Priming adult stem cells by hypoxic pretreatments for applications in regenerative medicine. J Biomed Sci 2013;20:63

18. Chang CP, Chio CC, Cheong CU, Chao CM, Cheng BC, Lin MT. Hypoxic preconditioning enhances the therapeutic potential of the secretome from cultured human mesenchymal stem cells in experimental traumatic brain injury. Clin Sci (Lond) 2013;124:165-176

19. Mottaghi S, Larijani B, Sharifi AM. Apelin 13: a novel ap- proach to enhance efficacy of hypoxic preconditioned mesenchymal stem cells for cell therapy of diabetes. Med Hypotheses 2012;79:717-718

20. Watanabe S, Arimura Y, Nagaishi K, Isshiki H, Onodera K, Nasuno M, Yamashita K, Idogawa M, Naishiro Y, Murata M, Adachi Y, Fujimiya M, Imai K, Shinomura Y. Conditioned mesenchymal stem cells produce pleiotropic gut trophic factors. J Gastroenterol 2014;49:270-282

21. Liu H, Liu S, Li Y, Wang X, Xue W, Ge G, Luo X. The role of SDF-1-CXCR4/CXCR7 axis in the therapeutic effects of hypoxia-preconditioned mesenchymal stem cells for renal ischemia/reperfusion injury. PLoS One 2012;7:e34608

22. Yu X, Lu C, Liu H, Rao S, Cai J, Liu S, Kriegel AJ, Greene AS, Liang M, Ding X. Hypoxic preconditioning with cobalt of bone marrow mesenchymal stem cells improves cell migration and enhances therapy for treatment of ischemic acute kidney injury. PLoS One 2013;8:e62703

23. Yu J, Yin S, Zhang W, Gao F, Liu Y, Chen Z, Zhang M, He J, Zheng S. Hypoxia preconditioned bone marrow mesenchymal stem cells promote liver regeneration in a rat massive hepatectomy model. Stem Cell Res Ther 2013;4:83

24. Bonfield TL, Caplan AI. Adult mesenchymal stem cells: an innovative therapeutic for lung diseases. Discov Med 2010;9:337-345

25. Inamdar AC, Inamdar AA. Mesenchymal stem cell therapy in lung disorders: pathogenesis of lung diseases and mechanism of action of mesenchymal stem cell. Exp Lung Res 2013;39:315-327

26. Chacko SM, Ahmed S, Selvendiran K, Kuppusamy ML, Khan M, Kuppusamy P. Hypoxic preconditioning induces the expression of prosurvival and proangiogenic markers in mesenchymal stem cells. Am J Physiol Cell Physiol 2010; 299:C1562-C1570

27. Ohnishi S, Yasuda T, Kitamura S, Nagaya N. Effect of hypoxia on gene expression of bone marrow-derived mesenchymal stem cells and mononuclear cells. Stem Cells 2007; 25:1166-1177 